\title{
Título: COVID-19 pediatric mortality rates are heterogeneous between countries Título corto: COVID-19 pediatric mortality rates
}

${ }^{1}$ Nadia González-García, ${ }^{2}$ América Liliana Miranda-Lora, ${ }^{3} J u a n$ Garduño-Espinosa, ${ }^{4} J a v i e r$ T. Granados-Riverón, ${ }^{5}$ Jorge Fernando Méndez-Galván, ${ }^{6}$ Jaime Nieto-Zermeño, ${ }^{7}$ María F Castilla-Peón

${ }^{1}$ Hopital Infantil de México Federico Gómez. Laboratorio de Investigación en Neurociencias

${ }^{2}$ Hospital Infantil de México Federico Gómez. Unidad de Investigación en Medicina Basada en Evidencias

${ }^{3}$ Hospital Infantil de México Federico Gómez. Dirección de Investigación.

${ }^{4}$ Hospital Infantil de México Federico Gómez. Unidad de Investigación en Patogenésis Molecular.

${ }^{5}$ Jorge Fernando Méndez Galván Hospital Infantil de México Federico Gómez. Unidad de Investigación en Enfermedades Emergentes.

${ }^{6}$ Hospital Infantil de México Federico Gómez. Dirección General.

${ }^{7}$ Hospital Infantil de México Federico Gómez. Dirección de Investigación

Autor de correspondencia: María Fernanda Castilla Peón. Dirección de Investigación. Hospital Infantil de México Federico Gómez. Dirección: Dr. Márquez No. 162. Colonia Doctores, Delegación Cuauhtémoc, CP 06720, Ciudad de México. Teléfono 5228-9917. Correo electrónico: fernandacastillapeon@gmail.com

COVID-19 pediatric mortality rates are heterogenous between countries.

Short title: COVID-19 pediatric mortality rates.

Abstract 
medRxiv preprint doi: https://doi.org/10.1101/2020.09.17.20196832; this version posted September 19, 2020. The copyright holder for this preprint (which was not certified by peer review) is the author/funder, who has granted medRxiv a license to display the preprint in perpetuity. All rights reserved. No reuse allowed without permission.

Introduction: Severe COVID-19 is infrequent in children, with a lethality rate of about $0.08 \%$. This study aims to explore differences in the pediatric mortality rate between countries.

Methods: Countries with populations over 5 million that report COVID-19 deaths disaggregated data by quinquennial or decennial age groups were analyzed. Data were extracted from COVID-19 Cases and Deaths by Age Database, national ministries of health, and the World Health Organization.

Results: 23 countries were included in the analysis. Pediatric mortality varied from 0 to 12.1 deaths per million people of the corresponding age group, with the highest rate in Peru. In most countries, deaths were more frequent in the 0-4 years old age group, except for Brazil. The pediatric/ general COVID-19 mortality showed a great variation between countries and ranged from 0 (Republic of Korea) to $10.4 \%$ (India). Pediatric and Pediatric/general COVID mortality have a strong correlation with 2018 neonatal mortality $(r=0.77, p<0.001$ and $r=0.88, p<0.001$ respectively), while it has a moderate or absent $(r=0.47, p=0.02$ and $r=0.19$, $p=0.38$, respectively) correlation with COVID-19 mortality in the general population.

Conclusions: There is an important heterogenicity in pediatric COVI-19 mortality between countries that parallels historical neonatal mortality. Neonatal mortality is a known index of the quality of a country's Health System which points to the importance of social determinants of health in pediatric COVID-19 mortality disparities, an issue which should be further explored.

Keywords: COVID-19; mortality; infant; child; adolescent ; geographic location

\section{Introduction}

Since the first cases of coronavirus disease, 2019 (COVID-19) appeared in Wuhan, China, at the end of 2019, morbidity and mortality by SARS-CoV-2 have been significant in countries within every continent. Mortality is mostly concentrated in advanced age groups and the adult population with ongoing comorbidities (1-5). Children and adolescents constitute $2 \%$ and $9.5 \%$ of all reported cases in Europe and the USA, respectively. Severe COVID-19 is infrequent in children and intensive care unit admissions regarding this age group have been reported to be about $2 \%$ and lethality rate about $0.08 \%$ (6). Besides, preliminary evidence suggests that both ethnicity (Black and Hispanic) and age (under 1 month and early adolescence [10-14 years]) are associated with admission to a critical care unit. Moreover, children from low-income families or non-white ethnicity are more likely to test positive for SARS-CoV-2 than those of white ethnicity and high-income $(7,8)$. 
medRxiv preprint doi: https://doi.org/10.1101/2020.09.17.20196832; this version posted September 19, 2020. The copyright holder for this preprint (which was not certified by peer review) is the author/funder, who has granted medRxiv a license to display the preprint in perpetuity. All rights reserved. No reuse allowed without permission.

To date, COVID-19 epidemiologic data in the pediatric population has been published by some countries but there is a scarcity of analysis comparing different populations. The COVID-19 mortality rate in the population under 18 years of age, might be heterogeneous between countries with different incomes rates and ethnicities. Our aim with this brief report is to explore the differences in the COVID19 pediatric mortality rate between countries.

\section{Methods}

We included information about countries with populations over 5 million that reported COVID-19 deaths, disaggregated by quinquennial or decennial age groups. Data about confirmed COVID-19 death counts were consulted in the COVID-19 Cases and Deaths by Age Database (COVerAge-DB) (9), COVerAgeDB collects age- and sex-specific cumulative cases, deaths, and tests from official reports from multiple countries worldwide and for several subpopulations. Data from Argentina, Canada, and Peru, and Mexico were consulted from the local Ministries of Health (10-13) Data from countries that disaggregate data by decennial age groups, were estimated according to the countries age structure available data.

For the computation of age-specific mortality rates, we obtained both the total and quinquennial age groups estimated populations for 2018 or the latest available year from the United Nations Statistics Division Web site, (14). Data for general COVID-19 mortality were extracted from the World Health Organization (WHO) reports (15).

In an exploratory analysis, we also calculated the Spearman's correlation coefficient between pediatric COVID-19 mortality rates with general mortality rates and newborn mortality by any cause in 2018 (before the COVID-19 pandemic). STATA $13.0 \AA$ was used for the analysis.

\section{Results}

We included 23 countries in the analysis. Table 1 shows the general mortality and pediatric mortality rates from COVID-19. Specifically, 63\% of deaths in the population of $<15$ years of age at the time of the study occurred in India $(\mathrm{n}=$ 1,622). However, when adjusting the mortality per million people for this age group, the highest rates were observed in Latin American countries (Peru, Brazil, Ecuador, and Mexico). Although Peru also has the highest overall mortality rate from COVID-19, it is followed by European countries (United Kingdom, Spain, and Italy). On the other hand, the highest pediatric to general population ratio of COVID-19 mortality was identified in Asian countries (India, Indonesia, and the Philippines). 
medRxiv preprint doi: https://doi.org/10.1101/2020.09.17.20196832; this version posted September 19, 2020. The copyright holder for this preprint (which was not certified by peer review) is the author/funder, who has granted medRxiv a license to display the preprint in perpetuity. All rights reserved. No reuse allowed without permission.

Table 2 shows the pediatric mortality by quinquennial age groups. The highest mortality in children under 10 years old was observed in Peru and the highest mortality in children older than 10 years old was in Brazil.

We found a significant strong correlation between both the COVID-19 pediatric mortality and the pediatric/general COVID-19 mortality ratio and the 2018 neonatal mortality $(r=0.77, p<0.001$ and $r=0.88, p<0.001$ respectively), while there was a moderate or absent correlation with COVID-19 mortality in the general population. $(r=0.47, p=0.02$ and $r=0.19, p=0.38$, respectively) (Table 3$)$.

\section{Discussion}

Despite COVID-19 mortality in children is minimal in comparison with that in the adult population, there is significant heterogeneity between countries. Several factors should be explored to explain this variability. This report was elaborated with available data from different sources and differences in reporting systems of epidemiological information may be accountable for some of the variation.

Remarkably, the highest pediatric mortality rates are among countries of uppermiddle-income countries in contrast with high-income countries (data for lower and lower-middle-income countries were not available). This is true even for highincome countries that have suffered from high mortality rates in the general population which, despite this, have a low pediatric/general COVID mortality rate ratio (adjusted for age structure).

In most countries, the COVID mortality rate in the pediatric population is concentrated in the under 5-year-old population. Brazil has a disproportionately high mortality rate in adolescents and the causes of this must be studied. In Mexico, about half of the deaths in the 0-4 age group are in infants < 1 -year-old. It is important to have disaggregated data for age to estimate the share of child mortality which corresponds to neonatal and infant mortality.

Child, infant, and neonatal mortality are known indicators of the quality of health care systems(16). It is noticeable that pediatric COVID mortality and pediatric/general COVID-19 rate ratio are highly correlated with historical basal neonatal mortality while it is only moderately correlated with general COVID-19 mortality. These findings suggest an important role of social determinants of health as well as the quality of health care systems in discrepancies of pediatric COVID19 mortality rates between countries. The relative importance of this set of factors over biological factors remains to be established. 
Table 1 . Mortality indices by COVID-19 and neonatal mortality in 2018 by country.

\begin{tabular}{|c|c|c|c|c|c|c|}
\hline Country & $\begin{array}{c}\text { COVID- } \\
19 \\
\text { Deaths } \\
\text { in } \\
\text { populati } \\
\text { on }<15 \\
\text { years of } \\
\text { age }\end{array}$ & $\begin{array}{l}\text { COVID- } \\
19 \\
\text { Mortality } \\
\text { rate in } \\
<15 \text { years } \\
\text { of age, } \\
\text { per } \\
\text { million } \\
\text { people }\end{array}$ & $\begin{array}{l}\text { COVI } \\
\text { D-19 } \\
\text { Mortal } \\
\text { ity } \\
\text { rate in } \\
\text { gener } \\
\text { al } \\
\text { popul } \\
\text { ation } \\
\text { per } \\
\text { millio } \\
\text { n } \\
\text { peopl } \\
\text { e } \\
(23 / 08 / \\
20)\end{array}$ & $\begin{array}{c}\text { Pediatr } \\
\text { ic/ } \\
\text { Genera } \\
\text { I } \\
\text { COVID } \\
-19 \\
\text { mortali } \\
\text { ty rate } \\
\text { ratio } \\
(\%)\end{array}$ & $\begin{array}{c}\text { Neonatal } \\
\text { mortality } \\
\text { (every } \\
\text { cause) } \\
\text { per } 1000 \\
\text { alive } \\
\text { newborns } \\
\text { in } 2018\end{array}$ & 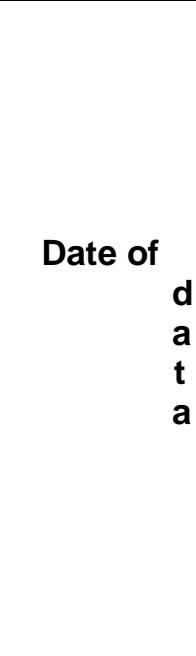 \\
\hline Peru & 94 & 12.1 & 852 & 1.4 & 7.3 & $09 / 08 / 2020$ \\
\hline Brazil $^{\text {ab }}$ & 405 & 8.8 & 541 & 1.6 & 8.1 & $02 / 08 / 2020$ \\
\hline Ecuador $^{b}$ & 25 & 5.5 & 367 & 1.5 & 7.2 & $13 / 08 / 2020$ \\
\hline Mexico & 169 & 5.1 & 472 & 1.5 & 7.5 & $18 / 08 / 2020$ \\
\hline $\operatorname{India}^{a}$ & 1622 & 4.35 & 42 & 10.4 & 22.7 & $05 / 08 / 2020$ \\
\hline Chile & 15 & 4.1 & 576 & 0.7 & 4.9 & $05 / 08 / 2020$ \\
\hline Colombia & 29 & 2.9 & 334 & 0.9 & 7.8 & $05 / 08 / 2020$ \\
\hline Indonesia ${ }^{\text {ab }}$ & 88 & 1.3 & 25 & 5.2 & 12.7 & $05 / 05 / 2020$ \\
\hline Philippines ${ }^{\text {ac }}$ & 40 & 1.2 & 29 & 4.3 & 13.5 & $05 / 08 / 2020$ \\
\hline Argentina $^{\mathrm{a}}$ & 13 & 1.1 & 153 & 0.7 & 6.4 & $10 / 08 / 2020$ \\
\hline Spain $^{a}$ & 5 & 0.8 & 616 & 0.1 & 1.7 & $21 / 05 / 2020$ \\
\hline $\begin{array}{l}\text { United States of } \\
\text { America }^{a}\end{array}$ & 46 & 0.8 & 533 & 0.1 & 3.5 & 01/08/2020 \\
\hline United Kingdom & 7 & 0.6 & 623 & 0.1 & 2.6 & $05 / 08 / 2020$ \\
\hline Sweden $^{a}$ & 1 & 0.6 & 571 & 0.1 & 1.5 & $05 / 08 / 2020$ \\
\hline Italy & 4 & 0.6 & 586 & 0.1 & 2 & $28 / 07 / 2020$ \\
\hline France & 4 & 0.35 & 454 & 0.1 & 2.54 & $12 / 07 / 2020$ \\
\hline Canada $^{2}$ & 1 & 0.1 & 245 & 0.1 & 3.4 & $26 / 08 / 2020$ \\
\hline Germany $^{\mathrm{a}}$ & 1 & 0.1 & 111 & 0.1 & 2.2 & $05 / 08 / 2020$ \\
\hline Australia $^{a}$ & 0 & 0 & 19 & 0 & 2.3 & $05 / 08 / 2020$ \\
\hline Austria & 0 & 0 & 83 & 0 & 2.1 & $05 / 08 / 2020$ \\
\hline Finland & 0 & 0 & 61 & 0 & 1 & $05 / 08 / 2020$ \\
\hline Greece & 0 & 0 & 22 & 0 & 2.6 & $05 / 08 / 2020$ \\
\hline Republic of Korea & 0 & 0 & 6 & 0 & 1.5 & $05 / 08 / 2020$ \\
\hline \multicolumn{7}{|c|}{$\begin{array}{l}\text { a Countries that do not repport data disaggregated by quinquennial age groups. } \\
{ }^{b} \text { Latest population data available were from } 2010 \\
\text { c Latest population data vailable were form } 2015\end{array}$} \\
\hline
\end{tabular}


Table 2. COVID-19 Mortality rate by quinquennial age groups and country.

\begin{tabular}{|c|c|c|c|c|c|c|}
\hline Country & $\begin{array}{l}\text { COVID- } \\
19 \\
\text { Deaths } \\
\text { in the } \\
\text { popula } \\
\text { tion } \\
\text { aged 0- } \\
4 \text { years }\end{array}$ & $\begin{array}{l}\text { COVID-19 } \\
\text { Mortality } \\
\text { rate in the } \\
\text { population } \\
\text { aged 0-4 } \\
\text { years (per } \\
\text { million) }\end{array}$ & $\begin{array}{c}\text { COVI } \\
\text { D-19 } \\
\text { Death } \\
\text { s in } \\
\text { the } \\
\text { popul } \\
\text { ation } \\
\text { aged } \\
5-9 \\
\text { years } \\
\text { (per } \\
\text { millio } \\
\text { n) }\end{array}$ & $\begin{array}{l}\text { COVID-19 } \\
\text { Mortality } \\
\text { rate in the } \\
\text { population } \\
\text { aged 5-9 } \\
\text { years (per } \\
\text { million) }\end{array}$ & $\begin{array}{c}\text { COVID- } \\
19 \\
\text { Deaths } \\
\text { in the } \\
\text { popula } \\
\text { tion } \\
\text { aged } \\
10-14 \\
\text { years }\end{array}$ & $\begin{array}{c}\text { COVID- } \\
19 \\
\text { Mortality } \\
\text { rate in } \\
\text { the } \\
\text { populati } \\
\text { on aged } \\
10-14 \\
\text { years } \\
\text { (per } \\
\text { million) }\end{array}$ \\
\hline Peru & 40 & 16.04 & 29 & 10.96 & 25 & 9.57 \\
\hline India ${ }^{a}$ & 1519.1 & 13.47 & 20.5 & 0.16 & 82.2 & 0.62 \\
\hline Mexico & 108 & 9.85 & 25 & 2.25 & 36 & 3.22 \\
\hline Ecuador $^{\mathrm{b}}$ & 11 & 7.52 & 7 & 4.58 & 7 & 4.55 \\
\hline Chile & 9 & 7.24 & 3 & 2.40 & 3 & 2.52 \\
\hline Colombia & 15 & 4.94 & 9 & 2.70 & 5 & 1.38 \\
\hline Brazil $^{\text {ab }}$ & 38.2 & 2.77 & 103.8 & 6.93 & 263.1 & 15.33 \\
\hline Philippines ${ }^{\mathrm{ac}}$ & 26 & 2.40 & 7 & 0.65 & 7 & 0.67 \\
\hline Indonesia ${ }^{\text {ab }}$ & 47.4 & 2.09 & 22.3 & 0.96 & 18.4 & 0.81 \\
\hline United States of America $^{a}$ & 25.3 & 1.28 & 8.1 & 0.40 & 12.2 & 0.58 \\
\hline Argentina (5) ${ }^{a}$ & 3.5 & 0.94 & 3.5 & 0.94 & 5.5 & 1.56 \\
\hline Italy & 2 & 0.82 & 2 & 0.82 & 0 & 0 \\
\hline United Kingdom & 3 & 0.76 & 1 & 0.24 & 3 & 0.79 \\
\hline Sweden $^{2}$ & 0.4 & 0.66 & 0.6 & 0.98 & 0 & 0 \\
\hline Spain $^{a}$ & 0.9 & 0.43 & 1.9 & 0.78 & 2.5 & 1.02 \\
\hline France & 1 & 0.28 & 2 & 0.5 & 1 & 0.25 \\
\hline Germany $^{\mathrm{a}}$ & 1 & 0.26 & 0 & 0.00 & 0 & 0 \\
\hline Canada $(6)^{\mathrm{a}}$ & 0.25 & 0.13 & 0.25 & 0.12 & 0.25 & 0.13 \\
\hline Australia & 0 & 0 & 0 & 0 & 0 & 0 \\
\hline Austria & 0 & 0 & 0 & 0 & 0 & 0 \\
\hline Finland & 0 & 0 & 0 & & 0 & 0 \\
\hline Greece & 0 & 0 & 0 & 0 & 0 & 0 \\
\hline Republic of Korea & 0 & 0 & 0 & 0 & 0 & 0 \\
\hline
\end{tabular}




\section{Table 3. Spearman correlation coefficient between pediatric COVID-19 mortality, general COVID-19 mortality, Neonatal mortality in 2018, and Pediatric/General COVID-19 mortality rate ratio.}

\begin{tabular}{|l|l|l|l|}
\hline & $\begin{array}{l}\text { COVID-19 } \\
\text { Mortality rate } \\
\text { in <15 years } \\
\text { of age, }\end{array}$ & $\begin{array}{l}\text { COVID-19 } \\
\text { Mortality rate } \\
\text { in the general } \\
\text { population }\end{array}$ & $\begin{array}{l}\text { Neonatal mortality } \\
\text { in 2018 }\end{array}$ \\
\hline $\begin{array}{l}\text { COVID-19 } \\
\text { Mortality rate in } \\
<15 \text { years of age }\end{array}$ & - & $0.47^{\mathrm{b}}$ & $0.77^{\mathrm{a}}$ \\
\hline $\begin{array}{l}\text { COVID-19 } \\
\text { Mortality rate in } \\
\text { general } \\
\text { population }\end{array}$ & $0.47^{\mathrm{b}}$ & - & -0.03 \\
\hline $\begin{array}{l}\text { Pediatric/ General } \\
\text { COVID-19 } \\
\text { mortality rate }\end{array}$ & $0.9^{\mathrm{a}}$ & 0.19 & $0.88^{\mathrm{a}}$ \\
ratio & & & \\
\hline $\begin{array}{l}\mathrm{a} \text { p }<0.001 \\
\mathrm{~b}<0.05\end{array}$ & & & \\
\hline
\end{tabular}

\section{References}

1. Onder G, Rezza G, Brusaferro S. Case-Fatality Rate and Characteristics of Patients Dying in Relation to COVID-19 in Italy. JAMA. 2020.

2. Richardson S, Hirsch JS, Narasimhan M, Crawford JM, McGinn T, Davidson KW, et al. Presenting Characteristics, Comorbidities, and Outcomes Among 5700 Patients Hospitalized With COVID-19 in the New York City Area. JAMA. 2020.

3. Williamson EJ, Walker AJ, Bhaskaran K, Bacon S, Bates C, Morton CE, et al. Factors associated with COVID-19-related death using OpenSAFELY. Nature. 2020;584(7821):4306.

4. Petrilli CM, Jones SA, Yang J, Rajagopalan H, O'Donnell L, Chernyak $\mathrm{Y}$, et al. Factors associated with hospital admission and critical illness among 5279 people with coronavirus disease 2019 in New York City: prospective cohort study. BMJ. 2020;369:m1966.

5. Zhou F, Yu T, Du R, Fan G, Liu Y, Liu Z, et al. Clinical course and risk factors for mortality of adult inpatients with COVID-19 in Wuhan, China: a retrospective cohort study. Lancet. 2020;395(10229):1054-62. 
6. Liguoro I, Pilotto C, Bonanni M, Ferrari M, Pusiol A, Nocerino A, et al. SARS-COV-2 infection in children and newborns: a systematic review. Eur J Pediatr. 2020;179(7).

7. Jenco M. Study: $33 \%$ of children hospitalized with COVID-19 admitted to ICU. AAP News. 2020 Aug, 07,2020.

8. Jenco M. Study: Hispanic, Black, low-income children had highest rates of SARS-

CoV-2. AAP News. 2020 Aug 05;2020.

9. Riffe T, Acosta E. COVerAGE-DB: A database of COVID-19 cases and deaths by age 2020 [cited 2020 05/08/20]. Available from: https://osf.io/mpwiq/.

10. Argentina.gob.ar 2020 [cited 2020 11/08/2020]. Ministerio de Salud

Argentina:[Availablefrom: https://www.argentina.gob.ar/salud/coronavirus-COVID19/sala-situacion.

11. Plataforma Nacional de Datos Abiertos: Ministerio de Salud de Perú; 2020

[Availablefrom: https://www.datosabiertos.gob.pe/dataset/fallecidos-por-covid-19ministerio-de-salud-minsa.

12. Coronavirus disease 2019 (COVID-19): Epidemiology update: Government of Canada; 2020 [cited 2020 26/08/2020].

13. Datos Abiertos - Dirección General de Epidemiología: Dirección General de Epidemiología, Secretaría de Salud, Gobierno de México; 2020 [Availablefrom: https://www.gob.mx/salud/documentos/datos-abiertos-152127.

14. UNdata A world of information: United Nations Statistics Division; 2020 [cited 2020 26/08/2020]. Available from:

http://data.un.org/Data.aspx?d=POP\&f=tableCode\%3A22\#POP.

15. WHO Coronavirus Disease (COVID-19) Dashboard: Geneva: World Health Organization; 2020 [Available from: https://covid19.who.int/.

16 RichardusJaH, Graafmans WC, Verloove-Vanhorick SP, Mackenbach JP. The Perinatal Mortality Rate as an Indicator of Quality of Care in International Comparisons. Medical Care. 1998;36(1):54-66. 